\title{
The Substantial Weight Test: A Proposal to Resolve the Circuits' Disparate Interpretations of Materiality Under the False Claims Act ${ }^{*}$
}

\section{INTRODUCTION}

The False Claims Act (FCA) ${ }^{1}$ is a federal statute that imposes civil liability on any person who presents or causes to be presented a false or fraudulent monetary claim for disbursement of United States governmental funds. ${ }^{2}$ While some form of the Act has been in force since the Civil War, ${ }^{3}$ courts are still unsure of how to interpret the widely-used statute. In particular, courts have been wildly inconsistent regarding materiality under the FCA. Before Congress passed the Fraud Enforcement and Recovery Act of 2009 (FERA), materiality was not an express element of the statute, ${ }^{4}$ and as a result, some circuits declined to recognize materiality as an element of an FCA claim. ${ }^{5}$ Other circuits held that materiality was implicitly required and should be considered. ${ }^{6}$ Those circuits finding materiality as an element of an FCA claim were and remain split on what test applies to determine materiality under the

\footnotetext{
Megan L. Hoffman. J.D. candidate 2010, University of Kansas School of Law; B.B.A. 2007, Baylor University. I would like to extend my gratitude to Professor Webb Hecker and Bonnie Boryca for their helpful comments and suggestions throughout the writing and editing process. I would also like to thank my family - particularly my husband Russ and my parents Kent and Terry - for their continued love, support, and encouragement in my personal and professional endeavors.

1. 31 U.S.C.A. $\S \S 3729-3733$ (West Supp. 2009); 18 U.S.C.A $\S 287$ (West Supp. 2009).

2. 31 U.S.C.A. $\S 3729$.

3. Daniel Engelberg, Nineteenth Survey of White Collar Crime: False claims, 41 AM. CRIM. L. REV. 527, 527 (2004).

4. See 31 U.S.C. $\$ 3729$ (2006), amended by 31 U.S.C.A. § 3729 (West Supp. 2009).

5. Carl Pacini \& Michael Bret Hood, The Role of Qui Tam Actions under the False Claims Act in Preventing and Deterring Fraud Against Government, 15 U. MiAMI BUS. L. REV. 273, 294 (2007) (citing James B. Helmer, Jr. \& Julie Webster Popham, Materiality and the False Claims Act, 71 U. Cin. L. Rev. 839, 841-42 (2003)). See also United States ex rel. Cantekin v. Univ. of Pittsburgh, 192 F.3d 402, 415 (3d Cir. 1999) (casting doubt on whether materiality is an element under the FCA, but declining to resolve the issue).

6. See United States v. Bourseau, 531 F.3d 1159, 1170-71 (9th Cir. 2008), cert. denied, 129 S. Ct. 1524 (2009); United States ex rel. A+ Homecare, Inc. v. Medshares Mgmt. Group, Inc., 400 F.3d 428, 441-42 (6th Cir. 2005); United States ex rel. Berge v. Bd. of Trs. of the Univ. of Ala., 104 F.3d 1453, 1459 (4th Cir. 1997).
} 
FCA. ${ }^{7}$ Although the United States Supreme Court has provided a general definition of "materiality,"- "a false statement is material if it has a "natural tendency to influence, or [is] capable of influencing, the decision of the decisionmaking body to which it was addressed" " - the definition has failed to provide guidance to the circuit courts in the context of the FCA. As a result of FERA, the FCA now defines "material" in $\S 3729(b)(4)$ as "having a natural tendency to influence, or be capable of influencing, the payment or receipt of money or property," which is clearly similar to the definition provided by the Supreme Court. Some circuits adopted a test from the Court's definition called the natural tendency test, which finds that the materiality of a false statement turns on "whether the false statement has a natural tendency to influence agency action or is capable of influencing agency action." 10 Other circuits have applied an outcome determinative test, which requires a showing that the alleged fraudulent actions had "the purpose and effect of causing the United States to pay out money it is not obligated to pay, or those actions which intentionally deprive the United States of money it is lawfully due ....".11

To resolve the discrepancies in finding liability under the FCA, circuit courts should all apply the same elements and the same tests to alleged false or fraudulent claims. Based on the legislative intent, common law of general fraud, and FERA, materiality is an element of a civil FCA claim. Because of the statute's unique remedial-punitive nature, courts should apply a more restrictive test than the natural tendency test $^{12}$ and a less restrictive test than the outcome determinative test. ${ }^{13}$ The test should be a substantial weight test: while the government need not actually have paid the false claim, the alleged false statement must be the type often considered by the government in the decisionmaking process, and its effect must be given substantial weight in the government's decision to pay the claim. Courts could apply this test, and thus the FCA, more uniformly and remain consistent with the general

7. United States v. Southland Mgmt. Corp., 288 F.3d 665, 675-76 (5th Cir. 2002) (describing the circuit split and the different tests applied in the circuits), aff'd on reh 'g, 326 F.3d 669 (5th Cir. 2003) (en banc).

8. Neder v. United States, 527 U.S. 1, 16 (1999) (citing United States v. Gaudin, 515 U.S. 506, 509 (1995)). The Court in Neder did not address an FCA claim; instead, the underlying claims were tax fraud, federal mail fraud, wire fraud, and bank fraud. Id. at 6 .

9. 31 U.S.C.A. § 3729(b)(4) (West Supp. 2009).

10. Bd. of Trs. of the Univ. of Ala., 104 F.3d at 1459 (citing United States v. Norris, 749 F.2d 1116, 1122 (4th Cir. 1984)).

11. Costner v. URS Consultants, Inc., 153 F.3d 667, 677 (8th Cir. 1998).

12. See infra Part III.B.1.

13. See infra Part III.B.2. 
definition of materiality set forth by the Supreme Court, FERA, and the purpose of the FCA as set forth in the legislative history.

To support these conclusions, this Note will analyze the legislative intent and statutory history of the FCA in Part II. Part III will describe the current status of the circuit splits with regard to the role of materiality in determining liability under the FCA. Part IV will set forth an analysis and a clearer description of the proposed substantial weight test.

\section{LEGISLATIVE AND JUdicial History OF THE FALSE Claims ACT}

The FCA was enacted "in 1863 to combat rampant fraud and corruption in the sale of supplies and provisions to the Union army during the Civil War." "14 The FCA's original civil penalties provided for "double the amount of damages suffered by the United States as a result of a false claim, plus a forfeiture of two thousand dollars for each false claim submitted." ${ }^{15}$ Because the primary purpose of these penalties was to provide restitution to the government for money it had been deprived of by fraud, the statute was intended to be a remedial one. ${ }^{16}$ In interpreting the FCA, the Supreme Court has agreed that it is remedial in nature. "We think the chief purpose of the [Act's civil penalties] was to provide for restitution to the government of money taken from it by fraud, and that the device of double damages plus a specific sum was chosen to make sure that the government would be made completely whole." 17

The Supreme Court, in United States $v$. Bramblett, explained that the original statute penalized presentment for payment or approval of false claims upon or against the government and any false statement made "for the purpose of obtaining, or aiding in obtaining, the approval or payment of such claim." 18 A statement or record under the FCA is a false assertion made as a part of the claim. ${ }^{19}$ In United States $v$. McNinch, the Supreme Court suggested that a "claim" under the FCA is a demand for money or property that induces the government to disburse funds or "otherwise suffer immediate financial detriment." ${ }^{, 20}$ If the false statement

\footnotetext{
14. Engelberg, supra note 3, at 527.

15. S. REP. NO. 99-345, at 8 (1986), reprinted in 1986 U.S.C.C.A.N. 5266, 5273.

16. Engelberg, supra note 3 , at 528 .

17. United States v. Bornstein, 423 U.S. 303, 314 (1976) (quoting United States ex rel. Marcus v. Hess, 317 U.S. 537, 551-52 (1943)), superseded by statute, 31 U.S.C. § 3729 (2006).

18. 348 U.S. 503, 505 (1955), overruled by Hubbard v. United States, 514 U.S. 695 (1995).

19. 31 U.S.C. § 3729(a)(2) (2006), amended by 31 U.S.C.A. § 3729(a)(1)(B) (West Supp.

20. 356 U.S. 595, 599 (1958). See also 31 U.S.C.A. § 3729(b)(2) (West Supp. 2009).
} 2009). 
is material or it "has a natural tendency to influence, or [is] capable of influencing, the decision of the decisionmaking body to which it was addressed," it makes the claim false. ${ }^{21}$ In its original form, the FCA protected the government from both false claims and false statements until 1948 when Congress split the FCA into two different statutes. ${ }^{22}$ Currently, the FCA contains both civil ${ }^{23}$ and criminal ${ }^{24}$ provisions. This Note discusses only the civil provision.

As the FCA evolved, it was used more generally to protect governmental funds and property from false or fraudulent claims. ${ }^{25}$ In fact, Congress has provided the FCA as the exclusive remedy for recovering damages from all attempts to cause the government to pay out money as a result of false or fraudulent claims. ${ }^{26}$ The Supreme Court stated that in enacting the FCA, "Congress wrote expansively, meaning to reach all types of fraud, without qualification, that might result in financial loss to the Government." 27 The FCA covers all claims to governmental money, even if a claimant does not have a direct connection to the government. ${ }^{28}$

Essentially, there are two actionable claims under the FCA: a standard claim and a reverse claim. ${ }^{29}$ A standard false claim is an attempt to receive payment from the government for false or fraudulent claims. $^{30}$ A reverse false claim is an attempt to conceal, avoid, or

21. Neder v. United States, 527 U.S. 1, 16 (1999) (citing United States v. Gaudin, 515 U.S. 506, $509(1995))$.

22. Engelberg, supra note 3, at 527 n.3. See Bramblett, 348 U.S. at 505-06 (explaining that the originally enacted statute penalized presentment for payment or approval of false claims upon or against the government and false statements made for the purpose of obtaining, or aiding in obtaining, the approval or payment of such claims).

23. $\S \S 3729-3733$.

24. 18 U.S.C.A. $\$ 287$ (West Supp. 2009).

25. Engelberg, supra note 3, at 527. See also United States v. Maher, 582 F.2d 842, 847-48 (4th Cir. 1978) (indicating that the FCA's purpose "is to assure the integrity of claims and vouchers submitted to the government"); Engelberg, supra note 3, at 527 n.3 (citing United States v. Gilliland, 312 U.S. 86, 93 (1941)) (stating the statutory language and history reveals Congress's intent "to protect the authorized functions of governmental departments and agencies from the perversion which might result from the deceptive practices").

26. United States ex rel. A+ Homecare, Inc. v. Medshares Mgmt. Group, Inc., 400 F.3d 428, 456 (6th Cir. 2005).

27. Id. (citing Cook County v. United States ex rel. Chandler, 538 U.S. 119, 129 (2003) (internal quotations omitted)).

28. 31 U.S.C.A. § 3729 (West Supp. 2009). This assertion is further supported by the Senate report in which Senator Leahy indicates that presentment to the government directly is not an element of an FCA claim and the FCA only requires that the claim be paid by governmental funds rather than directly to the claimant by the government. S. REP. NO. 111-10, at 10 (2009), reprinted in 2009 U.S.C.C.A.N. 430, 437-38.

29. $\$ 3729(\mathrm{a})$.

30. $§ 3729(\mathrm{a})(1)(\mathrm{A})$. 
decrease an obligation owed to the government by filing false documents. ${ }^{31}$ The FCA imposes liability when

(1) a person presents a claim for payment or approval or to decrease an obligation owed to the Government; (2) the claim is false or fraudulent; and (3) the person acted knowingly, defined as actual knowledge of the information, or with deliberate ignorance or reckless disregard of the truth or falsity of the information.

Liability also attaches when a person "knowingly makes [or] uses ... a false record or statement material to a false or fraudulent claim."

In 1986, Congress responded to an estimated thirty percent increase in contractor fraud cases. ${ }^{34}$ At this time, it was estimated that the United States was losing more than fifty billion dollars a year to false claims in all areas of government. ${ }^{35}$ Congress wanted to deter fraud against the government and took the opportunity to clarify the courts' confusion on the purpose and application of the FCA. ${ }^{36}$ Before 1986, courts were declaring that the FCA was penal in nature and that the government must prove its case by clear and convincing evidence to recover. ${ }^{37}$ Because Congress was "[f]rustrated with courts mandating higher burdens of proof for false claims," ${ }^{38}$ it also intended to reinforce its remedial purpose and to send a strong message to the courts that the FCA should be construed broadly. ${ }^{39}$ In the 1986 amendments, Congress clarified that the government's burden of proof for an FCA claim was by a preponderance of the evidence, the lowest standard. ${ }^{40}$ Additionally, Congress recognized that the "growing pervasiveness of fraud necessitates modernization of the Government's primary litigative tool. $" 41$

31. $§ 3729(\mathrm{a})(1)(\mathrm{G})$

32. United States ex rel. A+ Homecare, Inc. v. Medshares Mgmt. Group, Inc., 400 F.3d 428, 451 (6th Cir. 2005) (citing § 3729(b)).

33. $§ 3729(\mathrm{a})(1)(\mathrm{B})$.

34. S. REP. No. 99-345, at 2 (1986), reprinted in 1986 U.S.C.C.A.N. 5266, 5267.

35. Id. at 3 .

36. Id. at 7 .

37. Id. See also United States v. Ueber, 299 F.2d 310, 314 (6th Cir. 1962), superseded by statute 31 U.S.C. $\S 3731$ (c) (2006) (noting that the government must prove its FCA case by clear and convincing evidence).

38. Gregory G. Brooker, The False Claims Act: Congress Giveth and the Courts Taketh Away, 25 HAMLINE L. REV. 373, 380 (2002) (footnote omitted).

39. Engelberg, supra note 3, at 528. See also S. REP. No. 99-345, at 1 (stating that the basic purpose of the 1986 amendments was to make the FCA a more useful tool against fraud in modern times).

40. Brooker, supra note 38 , at 380 .

41. United States ex rel. A+ Homecare, Inc. v. Medshares Mgmt. Group, Inc., 400 F.3d 428, 
Prior to the 1986 amendments, the FCA provided for double damages and a maximum two thousand dollar civil penalty. ${ }^{42}$ The Supreme Court discussed this provision in 1976 and concluded "that the device of double damages plus a specific sum was chosen to make sure that the government would be made completely whole." ${ }^{43}$ One of the most significant changes Congress instituted with its 1986 amendments was the increase from double damages to treble damages. ${ }^{44}$ Due to this change, the Act took on a slight aspect of punishment. ${ }^{45}$ However, a fact finder's primary duty had not changed: "if it finds liability, its instruction is to return a verdict for actual damages," which a court may then multiply. ${ }^{46}$ In addition to the change to treble damages, the amendments also increased the civil penalties from two thousand dollars to "not less than $\$ 5,000$ and not more than $\$ 10,000 . " 47$ While it is arguable that the increase may have been due to Congress's desire to deter fraud against the government, the increase is most likely attributable to inflation. ${ }^{48}$

The amendments served their intended purpose and produced their intended effect. ${ }^{49}$ Since their enactment in 1986, claims under the FCA have been filed "in virtually all areas where governmental money is spent." 50 Some well-known or recent examples of FCA violations include healthcare fraud, ${ }^{51}$ submissions to the Federal Emergency Management Agency (FEMA) of false proof of loss claims after destruction caused by hurricanes, ${ }^{52}$ bid-rigging and defective pricing on

444 (6th Cir. 2005) (quoting S. REP. NO. 99-345, at 2).

42. United States v. Mackby, 339 F.3d 1013, 1019 (9th Cir. 2003).

43. Id. (quoting United States v. Bornstein, 423 U.S. 303, 314 (1976)).

44. S. REP. NO. 99-345, at 17.

45. Cook County v. United States ex rel. Chandler, 538 U.S. 119, 131-32 (2003).

46. Id. at 132

47. 31 U.S.C. $\$ 3729$ (a)(1) (2006), amended by 31 U.S.C.A. § 3729(a) (West Supp. 2009).

48. Two thousand dollars in 1863 was equal to approximately $\$ 17,850$ in 1986 . See The Inflation Calculator, http://www.westegg.com/inflation (last visited Oct. 1, 2009). Based on this result, the punitive impact of the forfeiture per false claim has, in effect, decreased.

49. Engelberg, supra note 3, at 528.

50. Id. See also All About Qui Tam, Common Types of Fraud Against the Government, http://www.allaboutquitam.orgfca common.shtml (last visited Aug. 26, 2009) (discussing the areas where the FCA could be used to combat fraud, including public works projects, federal government construction, research programs, customs, environmental clean-up programs, loan guarantees, agricultural subsidies, municipal bonds, and underpayment of oil and gas royalties on governmentleased land).

51. Stuart M. Gerson \& Jennifer E. Gladieux, Advice of Counsel: Eroding Confidentiality in Federal Health Care Law, 51 ALA. L. REV. 163, 170 (1999) (stating annual criminal convictions for health care fraud numbered only ninety in 1992, but exceeded 300 by 1997). See also United States v. Cabrera-Diaz, 106 F. Supp. 2d 234, 235-36 (D.P.R. 2000) (involving alleged false claims submitted to Medicare for anesthesia services).

52. Pacini \& Hood, supra note 5, at 275. 
governmentally funded housing projects, ${ }^{53}$ false certifications for entitlement to governmental benefits, ${ }^{54}$ and billing twice for the same work. ${ }^{55}$

In early 2009 in the "midst of [the United States's] most serious economic crisis since the Great Depression," ${ }^{56}$ Congress leapt into action with Senator Leahy at the helm to once again amend the FCA. ${ }^{57}$ While FERA's main aim was to "reinvigorate [the government's] capacity to investigate and prosecute the kinds of financial frauds that have so severely undermined our financial markets,"58 Congress was also concerned about fraud and abuse of more than one trillion dollars in stimulus funds. ${ }^{59}$ It declared the FCA as "[o]ne of the most successful tools for combating waste and abuse in Government spending" and is "used to recover funds lost to fraud and abuse."

With the 2009 amendments, Congress sought to clarify and correct interpretations of the FCA in Allison Engine Co. v. United States ex rel. Sanders $^{61}$ and United States ex rel. Totten v. Bombardier Corp. ${ }^{62}$ Congress sought to eliminate the requirement created in Allison Engine Co. that " a defendant must intend that the Government itself pay the claim." "63 This Supreme Court decision interpreted the FCA to require an element of intent that was not originally intended by Congress in passing the law. ${ }^{64}$ Additionally, it created a defense for entities that did not seek to defraud the government directly, but sought to defraud the government indirectly to receive governmental funds. ${ }^{65}$ To clarify that the FCA carries with it no requirement of intent on behalf of the defendant, FERA eliminated the phrase "to get" from former $\S$ 3729(a)(2) and "defraud the Government by getting a false or fraudulent

53. United States v. Ehrlich, 643 F.2d 634, 635 (9th Cir. 1981) (involving intentional overstatement of construction costs on a federally insured mortgage on a housing project).

54. Pacini \& Hood, supra note 5, at 275.

55. Al Munford, Inc. v. United States, 34 Fed. Cl. 62, 63-64 (1995), vacated, 86 F.3d 1178 (1996) (involving allegations that a construction company submitted dual claims for building and repairing wash racks at Fort McClellan, Alabama).

56. S. REP. NO. 111-10, at 2 (2009) reprinted in 2009 U.S.C.C.A.N. 430, 431.

57. Id. at 10 .

58. Id. at 3 .

59. Id. at 10

60. Id.

61. 128 S. Ct. 2123 (2008).

62. 380 F.3d 488 (D.C. Cir. 2004).

63. S. REP. No. 111-10, at 10 (quoting Allison Engine Co., 128 S. Ct. at 2128).

64. Id.

65. Id. 
claim allowed or paid" from former $\S 3729$ (a)(3). ${ }^{66}$ By passing FERA, Congress also sought to eliminate the presentment element created by the Court of Appeals for the District of Columbia Circuit in Totten. ${ }^{67}$ This decision also created a defense for individuals presenting claims to government grantees or contractors even though the claims were paid with government funds. ${ }^{68}$ As a result, Congress removed the "presentment clause" from the statute and amended the definition of "claim." 69

Additionally, although Congress did not change the civil penalties that can be assessed under the FCA with the 2009 amendments, it did create a provision to adjust them for inflation. ${ }^{70}$ With all the detailed changes to the FCA under FERA, the main purpose was to enforce and, once again, reinstate the broad, remedial purpose of the Act, which Congress considered particularly important in this economic climate with the disbursement of billions of dollars in government stimulus funds. ${ }^{71}$

\section{CURRENT Status OF THE CiRCUITS ON MATERIALITY IN THE CONTEXT OF THE FCA}

Although Congress enacted amendments in 1986 and 2009 to reduce ambiguity in applying the FCA, ${ }^{72}$ courts are still divided on how to interpret the statute. ${ }^{73}$ Prior to the 2009 amendments, some circuits interpreted the FCA to include a materiality requirement, others did not. $^{74}$ The Supreme Court did not directly resolve the issue. However, in the summer of 2008, the Supreme Court examined a similar issue under former 31 U.S.C. $\S 3729(a)(2) .^{75}$ Former $\S 3729$ (a)(2) imposed liability on a person who "knowingly makes, uses, or causes to be made

66. Id. at 12

67. Id. at 10 .

68. Id. at $10-11$.

69. Id. at 11; 31 U.S.C.A. § 3729(b)(2) (West Supp. 2009).

70. $\S 3729(\mathrm{a})(1)$.

71. S. REP. NO. 111-10, at 10 .

72. Id.; S. REP. No. 99-345, at 7 (1986), reprinted in 1986 U.S.C.C.A.N. 5266, 5272

73. See United States v. Southland Mgmt. Corp., 288 F.3d 665, 675-76 (5th Cir. 2002) (describing the circuit split and the different tests applied in the circuits), aff'd on reh' $g$, 326 F.3d 669 (5th Cir. 2003) (en banc).

74. See Pacini \& Hood, supra note 5, at 294 (2007) (citing James B. Helmer, Jr. \& Julie Webster Popham, Materiality and the False Claims Act, 71 U. CIN. L. REV. 839, 841-42 (2003)). See also United States ex rel. Cantekin v. Univ. of Pittsburgh, 192 F.3d 402, 415 (3d Cir. 1999) (casting doubt on whether materiality is an element under the FCA, but declining to resolve the issue).

75. Allison Engine Co. v. United States ex rel. Sanders, 128 S. Ct. 2123, 2125 (2008). 
or used, a false record or statement to get a false or fraudulent claim paid or approved by the Government."76 The Court held that "a plaintiff must prove that the defendant intended that the false statement be material to the Government's decision to pay or approve the false claim,",77 which created an intent element for FCA claims under $\S 3729$ (a)(2). The Court required that for a defendant to be liable under this section, he must have subjectively intended the false statement to be material to the government's decision to pay the claim. ${ }^{78}$ The creation of this additional requirement was one of the main reasons Congress passed the 2009 amendments. $^{79}$

Allison Engine Co. v. United States ex rel. Sanders did not resolve the dispute as to whether materiality is an independent element of an FCA claim, nor did it examine whether false statements must be material from the government's point of view when it objectively decides whether or not to pay a claim. ${ }^{80}$ However, Congress likely resolved the dispute over whether materiality is an element of an FCA claim when it removed the intent element from former $\S 3729$ (a)(2) by replacing "to get" with the phrase "material to." 81 Congress defined material as "having a natural tendency to influence, or be capable of influencing, the payment or receipt of money or property." $\$ 2$ Congress also added a materiality requirement to a reverse claim brought under $\S 3729(\mathrm{a})(1)(\mathrm{G}) .^{83}$

Therefore, the issue as to whether materiality is an element of $\S$ 3729(a)(1)(B) and (G) of the FCA has seemingly been resolved. However, Congress failed to resolve the issue of whether materiality is an element of an FCA claim under $\S 3729(\mathrm{a})(1)(A)$. Additionally, the issue remains as to the proper test to determine if a statement is indeed material. Many circuits have taken the vague definition of the Supreme Court in Neder v. United States, ${ }^{84}$ which is now the definition within the Act, ${ }^{85}$ and turned it into an even more ambiguous test called the natural 2009)

77. Allison Engine Co., 128 S. Ct. at 2125.

78. Id.

79. S. REP. No. 111-10, at 10-11 (2009) reprinted in 2009 U.S.C.C.A.N. 430, 437-38.

80. See generally Allison Engine Co., 128 S. Ct. at 2125.

81. S. REP. NO. 111-10, at 12.

82. 31 U.S.C.A. $§ 3729(b)(4)$ (West Supp. 2009).

83. $§ 3729(\mathrm{a})(1)(\mathrm{G})$.

84. 527 U.S. 1,16 (1999). In general, a false statement is material if it has a "natural tendency to influence, or [is] capable of influencing, the decision of the decisionmaking body to which it was addressed." Id. (citing United States v. Gaudin, 515 U.S. 506, 509 (1995)).

85. § 3729(b)(4). 
tendency test. ${ }^{86}$ Other circuits have applied a more rigid and restrictive outcome determinative test for finding materiality under the statute. ${ }^{87}$ Neither test seems to be supported by Congressional intent or the plain meaning of the statute.

\section{A. Materiality as an Element of the FCA}

Prior to the 2009 amendments, several circuit courts found or suggested that a civil action brought under the FCA requires a showing of materiality. ${ }^{88}$ These courts analyzed the statutory language, legislative history, and underlying purpose of the law for implicit support of an element of materiality even though there was no express requirement in the FCA. ${ }^{89}$ While the 2009 amendments creating an express requirement of materiality make the circuits' findings of implicit materiality somewhat moot regarding $\S 3729(\mathrm{a})(1)(\mathrm{B})$ and $(\mathrm{G})$, the analysis is important for three basic reasons. First, as support for the definition and requirement of materiality, Congress cited Neder v. United States and United States ex rel. A+ Homecare, Inc. v. Medshares Management Group, Inc. without giving any additional reasoning for adding the element. ${ }^{90}$ Presumably, Congress intended to adopt the Sixth Circuit's reasoning in Medshares Management Group for adding an element of materiality to the statute. Second, Congress's basis for adding the requirement is important in establishing what test should apply to determine whether the element has been met. Third, circuit courts have found that materiality is required under $\S 3729(\mathrm{a})(1)(\mathrm{A})$; however, Congress failed to make materiality an express requirement under that subsection. $^{91}$ Therefore, the issue remains as to whether materiality should be an element of a $\S 3729(\mathrm{a})(1)(\mathrm{A})$ claim.

86. United States v. Bourseau, 531 F.3d 1159, 1171 (9th Cir. 2008), cert. denied, 129 S.Ct. 1524 (2009); United States ex rel. Bahrani v. Conagra, Inc., 465 F.3d 1189, 1200 (10th Cir. 2006); United States ex rel. A+ Homecare, Inc. v. Medshares Mgmt. Group, Inc., 400 F.3d 428, 445-446 (6th Cir. 2005); United States ex rel. Berge v. Bd. of Trs. of the Univ. of Ala., 104 F.3d 1453, 1459 (4th Cir. 1997).

87. Mikes v. Straus, 274 F.3d 687, 696 (2d Cir. 2001); Costner v. URS Consultants, Inc., 153 F.3d 667, 677 (8th Cir. 1998); United States ex rel. Bidani v. Lewis, 264 F. Supp. 2d 612, 615 (N.D. Ill. 2003).

88. See Medshares Mgmt. Group, 400 F.3d at 442; United States v. Southland Mgmt. Corp., 326 F.3d 669, 679 (5th Cir. 2003) (en banc); United States ex rel. Costner v. URS Consultants, Inc., 317 F.3d 883, 887 (8th Cir. 2003); Luckey v. Baxter Healthcare Corp., 183 F.3d 730, 732 (7th Cir. 1999); United States ex rel. Berge, 104 F.3d at 1459; United States v. TDC Mgmt. Corp., 24 F.3d 292, 298 (D.C. Cir. 1994).

89. See, e.g., Medshares Mgmt. Group, 400 F.3d at 442.

90. S. REP. NO. 111-10, at 12 (2009), reprinted in 2009 U.S.C.C.A.N. 430, 439.

91. 31 U.S.C.A. § 3729(a)(1)(A) (West Supp. 2009). 
1. Prior to the 2009 Amendments, Circuit Courts Held Materiality as an Implicit Element of the FCA

In United States $v$. Wells, the Supreme Court established a three-step framework by which courts should interpret statutes: (1) a natural read of the full text; (2) the common-law meaning of the statutory terms; and (3) the statutory and legislative history. ${ }^{92}$ The Sixth Circuit in Medshares Management Group used this framework to determine that there is a materiality requirement under the FCA. ${ }^{93}$ Specifically the court stated, "[a]pplying the Wells framework to the FCA, we conclude that false statements or conduct must be material to the false or fraudulent claim to hold a person civilly liable under the FCA."94

a. The First Step of the Wells Framework and the FCA

In applying the first step of the Wells framework, the court found that a natural reading of the statute supported the presence of a materiality element under the FCA. $^{95}$ The court analyzed former 31 U.S.C. $\S$ 3729(a)(1), (2), and (7), ${ }^{96}$ now 31 U.S.C. $\$ 3729(\mathrm{a})(1)(\mathrm{A}),(\mathrm{B})$, and $(\mathrm{G}) .^{97}$ "Under the first subsection, the FCA imposes liability on "[a]ny person who knowingly presents, or causes to be presented, to an officer or employee of the United States Government... a false or fraudulent claim for payment or approval." "98 Claim was defined by former $\S$ 3729 (c) as "any request or demand ... for money or property ... [where] the United States Government provides any portion of the money or property which is requested or demanded." 99 Thus, the court concluded that liability under the FCA does not arise only because the claim includes a false statement, but "the claim itself must be false or

92. United States v. Wells, 519 U.S. 482, 490-92 (1997).

93. $400 \mathrm{~F} .3 \mathrm{~d}$ at 442 .

94. Id.

95. Id.

96. Id. at $442-43$.

97. 31 U.S.C.A. § 3729(a)(1)(A), (B), (G) (West Supp. 2009).

98. Medshares Mgmt. Group, 400 F.3d at 442 (quoting 31 U.S.C. § 3729(a)(1) (2006)). After the 2009 amendments, this subsection states "any person who ... knowingly presents, or causes to be presented, a false or fraudulent claim for payment or approval." 31 U.S.C.A. § 3729(a)(1)(A) (West Supp. 2009).

99. 31 U.S.C. $\$ 3729$ (c) (2006). After the 2009 amendments, claim is now defined in relevant part as "any request or demand ... for money or property ... [where] the United States Government provides or has provided any portion of the money or property requested or demanded." 31 U.S.C.A. § 3729(b)(2) (West Supp. 2009). 
fraudulent." "A false statement within a claim can only serve to make the entire claim itself fraudulent if that statement is material to the request or demand for money or property."101

Former subsection two imposed liability on a person who "knowingly makes, uses, or causes to be made or used, a false record or statement to get a false or fraudulent claim paid or approved by the Government." "102 As the Fifth Circuit stated, "[t]he express connection of a false statement with 'getting' a false claim paid is tantamount to requiring that the false statement be material to the payment decision."103 Essentially, one cannot get a false or fraudulent claim paid unless the false statement is important or material to the government's decisionmaking process.

Finally, the court analyzed former subsection seven, which imposed liability on any person who "knowingly makes, uses, or causes to be made or used, a false record or statement to conceal, avoid, or decrease an obligation to pay or transmit money or property to the Government." subsection of the FCA can only "avoid or decrease an obligation if that statement is material to the money or property owed to the

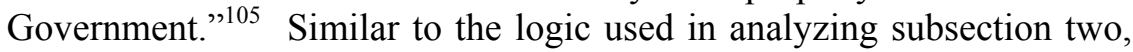
one cannot decrease an obligation to the government unless the false statement used was material to the government in its decision-making process.

100. Medshares Mgmt. Group, 400 F.3d at 443.

101. Id. (citing United States ex rel. Wilkins v. N. Am. Constr. Corp., 173 F. Supp. 2d 601, 624 (S.D. Tex. 2001)).

102. 31 U.S.C. § 3729(a)(2) (2000) (emphasis added). After the 2009 amendments, this subsection imposes liability on a person who "knowingly makes, uses, or causes to be made or used, a false record or statement material to a false or fraudulent claim.” 31 U.S.C.A. § 3729(a)(1)(B) (West Supp. 2009). Congress removed the phrase "to get" to ensure that no intent element would be read into the statute. S. REP. NO. 111-10, at 10 (2009), reprinted in 2009 U.S.C.C.A.N. 430, 43738.

103. United States v. Southland Mgmt. Corp., 326 F.3d 669, 679 (5th Cir. 2003) (en banc).

104. Medshares Mgmt. Group, 400 F.3d at 443 (quoting 31 U.S.C. § 3729(a)(7) (2000)). After the 2009 amendments, this subsection imposes liability on a person who "knowingly makes, uses, or causes to be made or used, a false record or statement material to an obligation to pay or transmit money or property to the Government, or knowingly conceals or knowingly and improperly avoids or decreases an obligation to pay or transmit money or property to the Government." 31 U.S.C.A. § 3729(a)(1)(G) (West Supp. 2009).

105. Medshares Mgmt. Group, 400 F.3d at 443. 
A district court also analyzed the literal language of the FCA in scholarly detail and arrived at the same conclusion. ${ }^{106}$ In its analysis, the court studiously considered the words of the statute, which led to

the conclusion that the defendant's statements or conduct that form the basis of an FCA complaint must result in a claim that is false or fraudulent. Statements or conduct make a claim false only if they are material to the defendant's entitlement to the money or property claimed.

The court concluded that

[a] natural reading of the term "false or fraudulent claim" is consistent with the implied materiality requirement that the courts have consistently recognized. By requiring a claim that is false or fraudulent, rather than a claim that contains false or fraudulent statements, the FCA implicitly requires statements or conduct that are material to the person's entitlement to the money or property claimed before liability can arise.

Accordingly, under a common reading and the plain meaning of the statute, there is an implicit materiality element required in bringing a claim under $\S 3729(\mathrm{a})(1)(\mathrm{A})$ of the FCA. ${ }^{109}$

b. The Second Step of the Wells Framework and the FCA

The second step in the Wells framework is to analyze the common law meaning of the words within the statute. ${ }^{110}$ The Supreme Court has reasoned that "the common law could not have conceived of 'fraud' without proof of materiality."111 For example, the Court in Neder $v$. United States applied the Wells framework ${ }^{112}$ to determine that materiality is a requirement for the crimes of mail fraud, ${ }^{113}$ wire fraud, ${ }^{114}$

106. United States ex rel. Wilkins v. N. Am. Constr. Corp., 173 F. Supp. 2d 601, 624-30 (S.D. Tex. 2001), abrogated by United States ex rel. Longhi v. United States, Nos. 08-20194 and 0820306, 2009 WL 1959259, at *7 (5th Cir. July 9, 2009).

107. Id. at 624 .

108. Id. (footnote omitted).

109. Medshares Mgmt. Group, 400 F.3d at 443.

110. United States v. Wells, 519 U.S. 482, 491 (1997).

111. Neder v. United States, 527 U.S. 1, 22 (1999)

112. Id. at 20 .

113. 18 U.S.C. $\S 1341$ (2006).

114. $\S 1343$. 
and bank fraud. ${ }^{115}$ These statutes, like the FCA prior to the 2009 amendments, do not expressly require a showing of materiality. ${ }^{116}$ However, "[i]t is a well-established rule of construction that '[w]here Congress uses terms that have accumulated settled meaning under ... the common law, a court must infer, unless the statute otherwise dictates, that Congress means to incorporate the established meaning of these terms." 117 Accordingly, the Court in its conclusion analyzed the term "fraud" and held that in using the term, Congress intended to "incorporate the 'well-settled meaning at common law,' which included proof of materiality." "118 In its decision, the Supreme Court declared, "we cannot infer from the absence of an express reference to materiality that Congress intended to drop that element from the fraud statutes." 119 In its conclusion, the Court stated "we must presume that Congress intended to incorporate materiality unless the statute otherwise dictates." 120 The same reasoning applies to the FCA — one must presume that Congress intended materiality to be an element unless the statute otherwise dictates. Therefore, the common law requires an element of materiality under $\S 3729(\mathrm{a})(1)(\mathrm{A})$ of the FCA.

c. The Third Step of the Wells Framework and the FCA

The last step in the Wells framework is to analyze the statutory and legislative history. ${ }^{121}$ The Senate report regarding the 1986 amendments states that the FCA was amended "to provide that an individual who makes a material misrepresentation to avoid paying money owed the Government would be equally liable under the Act as if he had submitted a false claim to receive money."122 Accordingly, the Sixth Circuit held that Congress implicitly required and intended materiality to be an element of an FCA claim. ${ }^{123}$

\footnotetext{
115. $§ 1344$.

116. See $\S \S 1341,1343,1344$.

117. Neder, 527 U.S. at 21 (citing Nationwide Mut. Ins. Co. v. Darden, 503 U.S. 318, 322 (1992)) (citations omitted).

118. Id. at 21-23.

119. $I d$. at 23 .

120. United States ex rel. A+ Homecare, Inc. v. Medshares Mgmt. Group, Inc., 400 F.3d 428, 442 (6th Cir. 2005) (citing Neder, 527 U.S. at 23).

121. United States v. Wells, 519 U.S. 482, 492 (1997).

122. Medshares Mgmt. Group, 400 F.3d at 444 (quoting S. REP. No. 99-345, at 18 (1986), reprinted in 1986 U.S.C.C.A.N. 5266, 5283) (emphasis added).

123. Id.
} 
An FCA claim brought under former 31 U.S.C. § 3729(a)(2) and (3) came before the Supreme Court in June 2008 in Allison Engine Co. ${ }^{124}$ The Court held that

[i]t is insufficient for a plaintiff asserting a § 3729(a)(2) claim to show merely that the false statement's use resulted in payment or approval of the claim .... Instead, such a plaintiff must prove that the defendant intended that the false statement be material to the Government's decision to pay or approve the false claim.

Subsection three imposes liability on a person who "conspires to defraud the Government by getting a false or fraudulent claim allowed or paid." 126 Similarly under former $\S 3729(\mathrm{a})(3)$, the Court held that "it must be established that [the alleged conspirators] agreed that the statement would have a material effect on the Government's decision to pay the false or fraudulent claim."127 The Court reasoned that the absence of a requirement of materiality under the intent element "would expand the FCA well beyond its intended role of combating "fraud against the Government." "128 Although Congress disagreed that the FCA should include an intent element, it did not discuss or analyze a requirement of materiality. ${ }^{129}$

While the Court's holding in Allison Engine Co. does not discuss whether materiality is an independent element of a $\S 3729$ (a)(1)(A) FCA claim or whether false statements must be material from the government's point of view in its decision-making process, the Court's logic can be equally applied to these issues. Without an objective requirement of materiality under this subsection, the FCA would be expanded beyond its intended purpose. Accordingly, by applying its logic in Allison Engine Co., it is clear that the Supreme Court would find that $\S 3729(\mathrm{a})(1)(\mathrm{A})$ of the FCA includes an element of materiality.

Materiality is, therefore, implicitly required under $\S 3729$ (a)(1)(A) of the FCA. A natural reading of the statute's text supports the presence of a requirement of materiality, and Congress implied the element of materiality within the common law meaning of the word "fraud."

\footnotetext{
124. Allison Engine Co. v. United States ex rel. Sanders, 128 S. Ct. 2123, 2125 (2008).

125. Id. (emphasis added).

126. 31 U.S.C. § 3729(a)(3) (2006), amended by 31 U.S.C.A. § 3279(a)(1)(C) (West Supp.

127. Allison Engine Co., 128 S. Ct. at 2125-26.

128. Id. at 2128 .

129. See S. REP. No. 111-10, at 10 (2009), reprinted in 2009 U.S.C.C.A.N. 430, 437-38.
} 2009) 
Without a requirement of materiality under $\S 3729(\mathrm{a})(1)(\mathrm{A})$, the FCA would be expanded beyond its original purpose intended by Congress.

\section{B. Circuits Are Split on the Test for Materiality in the Context of the FCA}

The Court has provided little guidance on the definition of materiality and no guidance with respect to the test for materiality under the FCA. ${ }^{130}$ In Neder $v$. United States, a federal mail fraud, wire fraud, and bank fraud case, the Court articulated a broad and general definition of materiality. ${ }^{131}$ "In general, a false statement is material if it has 'a natural tendency to influence, or [is] capable of influencing, the decision of the decisionmaking body to which it was addressed." "132 The Supreme Court adopted this general formulation of materiality "because the judgment in question [i.e. of materiality] does not lend itself to mechanical resolution." "133 Congress adopted this definition of "material" in $\S 3729$ (b)(4). ${ }^{134}$ Even though the Court and Congress have provided little guidance on an appropriate test for materiality under the FCA, ${ }^{135}$ the circuits have attempted to formulate a working test from the general definition provided in Neder. However, the circuits currently disagree about what test should be used to determine materiality. The Fourth, ${ }^{136}$ Sixth, ${ }^{137}$ Ninth, ${ }^{138}$ and Tenth ${ }^{139}$ Circuits have all applied the natural tendency test, while the Second ${ }^{140}$ and Eighth ${ }^{141}$ Circuits have applied the outcome determinative test.

130. See Neder v. United States, 527 U.S. 1, 16 (1999).

131. Id.

132. Id. (quoting United States v. Gaudin, 515 U.S. 506, 509 (1995)).

133. United States v. Southland Mgmt. Corp., 326 F.3d 669, 679 (5th Cir. 2003) (en banc) (quoting Kungys v. United States, 485 U.S. 759, 771 (1988)).

134. 31 U.S.C.A. $\$ 3729$ (b)(4) (West Supp. 2009).

135. Although Congress cited the Sixth Circuit's Medshares Management Group for support of this definition, it neither approved nor disapproved of use of the natural tendency test to determine materiality. S. REP. No. 111-10, at 12, n.6 (2009), reprinted in 2009 U.S.C.C.A.N. 430, 439. Additionally, it also cited circuits that apply the outcome determinative test as support for the definition. Id

136. United States ex rel. Berge v. Bd. of Trs. of the Univ. of Ala., 104 F.3d 1453, 1459 (4th Cir. 1997).

137. United States ex rel. A+ Homecare, Inc. v. Medshares Mgmt. Group, Inc., 400 F.3d 428, 444 (6th Cir. 2005).

138. United States v. Bourseau, 531 F.3d 1159, 1170 (9th Cir. 2008).

139. United States ex rel. Bahrani v. Conagra, Inc., 465 F.3d 1189, 1204 (10th Cir. 2006).

140. Mikes v. Straus, 274 F.3d 687, 696 (2d Cir. 2001).

141. Costner v. URS Consultants, Inc., 153 F.3d 667, 677 (8th Cir. 1998). 


\section{Natural Tendency Test}

The name for this test stems from the definition of materiality provided by the Court in Neder. ${ }^{142}$ The courts essentially turned this vague statement - that a false statement is material if it has "a natural tendency to influence, or [is] capable of influencing, the decision of the decisionmaking body to which it was addressed"-into a standard by which materiality is determined under the FCA. ${ }^{143}$ Under the natural tendency test, courts should consider "whether the false statement has a natural tendency to influence agency action or is capable of influencing agency action." 144

The Sixth Circuit in Medshares Management Group has probably provided the strongest assessment and analysis for using this test. ${ }^{145}$ The court declared that this standard "focuses on the potential effect of the false statement when it is made, not on the actual effect of the false statement when it is discovered" 146 and is thus "more consistent with the plain meaning of the statute, which attaches liability upon presentment of a false or fraudulent claim, rather than actual payment on that claim."147 The court also reasoned that "liability under the FCA is punishable by a civil penalty in addition to any damages which the Government actually sustains, which reinforces the conclusion that the actual result is not dispositive of liability under the FCA." ${ }^{148}$ Essentially, the court was using the logic that "there is no language in section 3729(a)(1) that mandates actual payment by the government or the need to establish damages." $" 149$

Additionally, the court declared that the natural tendency test is more consistent with the purpose of the FCA:

\footnotetext{
142. Neder v. United States, 527 U.S. 1, 16 (1999).

143. Id. (quoting United States v. Gaudlin, 515 U.S. 506, 509 (1995)).

144. United States ex rel. Berge v. Bd. of Trs. of the Univ. of Ala., 104 F.3d 1453, 1460 (4th Cir. 1997) (quoting United States v. Norris, 749 F.2d 1116, 1122 (4th Cir. 1984)).

145. United States ex rel. A+ Homecare, Inc. v. Medshares Mgmt. Group, Inc., 400 F.3d 428, 445-46 (6th Cir. 2005).

146. Id. at 445 (quoting United States ex rel. Harrison v. Westinghouse Savannah River Co., 352 F.3d 908, 916-17 (4th Cir. 2003)).

147. Id. (citing 31 U.S.C. § 3729(a)(1) (2006), amended by 31 U.S.C.A. § 3279(a)(1)(A) (West Supp. 2009)).

148. Id. at 446 .

149. Brooker, supra note 38, at 394. See also Joan H. Krause, Health Care Providers and the Public Fisc: Paradigms of Government Harm Under the Civil False Claims Act, 36 GA. L. REv. 121, 163-64 (2001) ("The statutory language supports the view that proof of damages is not a prerequisite for suit under the FCA.”).
} 
[E]valuating materiality based on the potential effect rather than actual result is more consistent with the underlying purpose of the FCA. The United States Supreme Court has broadly interpreted the statute to cover all fraudulent attempts to cause the Government to pay out sums of money. We have similarly held that recovery under the FCA is not dependent upon the government's sustaining monetary damages. These holdings are consistent with the FCA's principal goal of ensuring the integrity of the Government's dealings, which is embodied in the maxim that $[\mathrm{m}] \mathrm{en}$ must turn square corners when they deal with the Government.

Therefore, the focus of the natural tendency test is on the potential effect of the false statement or claim rather than its actual effect.

\section{Outcome Determinative Test}

In contrast, some circuits apply the more restrictive outcome determinative test, which was derived from the text of the FCA. This test "requires a showing that the alleged fraudulent actions had 'the purpose and effect of causing the United States to pay out money it is not obligated to pay, or those actions which intentionally deprive the United States of money it is lawfully due.",151 In applying this test, the Eighth Circuit has held that "where the plaintiff cannot show that the government agency would have acted differently had it known of the omission, 'there is no false claim because [the agency's action] would have occurred regardless of [the defendant's] actions." 152

In coming to its conclusion, the Eighth Circuit looked to previous Supreme Court decisions analyzing the definition of "claim" under the FCA. ${ }^{153}$ In 1958, the Supreme Court indicated in United States $v$. McNinch, "that a 'claim' under the FCA is a 'demand for money' that induces the government to disburse funds or 'otherwise suffer immediate financial detriment." "154 Accordingly, the court concluded that

only those actions by the claimant which have the purpose and effect of causing the United States to pay out money it is not obligated to pay, or those actions which intentionally deprive the United States of money it

\footnotetext{
150. Medshares Mgmt. Group, 400 F.3d at 446 (internal quotations and citations omitted).

151. Id. at 445 (quoting Costner v. URS Consultants, Inc., 153 F.3d 667, 677 (8th Cir. 1998)).

152. Id. (quoting Rabushka ex rel. United States v. Crane Co., 122 F.3d 559, 563 (8th Cir.

153. Costner v. URS Consultants, Inc., 153 F.3d 667, 677 (8th Cir. 1998).

154. Id. (quoting United States v. McNinch, 356 U.S. 595, 599 (1958)).
} 1997)). 
is lawfully due, are properly considered "claims" within the meaning of the FCA. ${ }^{15}$

Similarly, the Fifth Circuit applied the outcome determinative test to a claim under former 31 U.S.C. $§ 3729$ (a)(2). ${ }^{156}$ It reasoned that this subsection of the FCA prohibits the submission of a false record or statement, but "it does so only when the submission of the record or statement was done in an attempt to get a false claim paid. There is no liability under [the FCA] for a false statement unless it is used to get a false claim paid." 157 The court placed significant weight on the "express connection of a false statement with 'getting' a false claim paid" and declared it "tantamount to requiring that the false statement be material to the payment decision." 158 For this proposition, the court cited and based its reasoning on Hutchins v. Wilentz, Goldman \& Spitzer, which declares that the FCA "was not intended to impose liability for every false statement made to the government."159 By using the outcome determinative test, the court held that "[i]t is only those claims for money or property to which a defendant is not entitled that are 'false' for purposes of the False Claims Act." 160

\section{Substantial Weight Test Proposal}

The Supreme Court has provided little guidance in interpreting the FCA and has seemingly contradicted itself regarding the definition of materiality and the purpose of the statute. The problem has been exacerbated by lower courts' difficulty in carefully reading the statute and applying the Supreme Court's interpretations. Because the status of the FCA in the courts is in such disarray, a unifying standard must be put in place to preserve the fraud deterrence purpose of the statute. Otherwise, as some have speculated, "Congress may be forced to once again enact amendments to the FCA in order to restore the $[\mathrm{FCA}]$ as a

\footnotetext{
155. Id. (emphasis added).

156. United States v. Southland Mgmt. Corp., 326 F.3d 669, 675 (5th Cir. 2003) (en banc).

157. Id.

158. Id. at 679 .

159. Id. at 675 (citing Hutchins v. Wilentz, Goldman \& Spitzer, 253 F.3d 176, 184 (3d Cir. 2001)).

160. Id. at 674-75 (citing Costner v. URS Consultants, Inc., 153 F.3d 667, 677 (8th Cir. 1998); United States ex rel. Wilkins v. N. Am. Constr. Corp., 173 F. Supp. 2d 601, 626 (S.D. Tex. 2001)).
} 
broad-based tool for combating fraud in federal programs and procurement." 161

The lower courts' confusion is inhibiting the statute's effectiveness in fighting fraud against the government. The courts need a simple test that is consistent with Congress's objective in adopting the statute-to deter fraud and provide restitution to the government for its losses from false claims. However, the test must not be so broad as to include trivial falsehoods that are outside the purview of the statute. The test should be a substantial weight test: while the government need not actually have paid out on the false claim, the alleged false statement must be the type often considered by the government in the decision-making process, and its effect must be given substantial weight in the government's decision with respect to payment of the claim.

\section{A. Congress Intended the FCA to Be Restitutionary}

The Senate Report accompanying the 1986 amendments to the FCA expressly stated that "[t]he purpose of [the amendments] is to enhance the Government's ability to recover losses sustained as a result of fraud against the Government."162 The Supreme Court has supported this purpose by indicating that "the [FCA's] primary purpose is to indemnify the government - through its restitutionary penalty provisions - against losses caused by a defendant's fraud."163 The following excerpt from a Second Circuit case eloquently sets forth the underlying purpose of the statute.

Since the Act is restitutionary and aimed at retrieving ill-begotten funds, it would be anomalous to find liability when the alleged noncompliance would not have influenced the government's decision to pay. Accordingly, while the Act is intended to reach all types of fraud, without qualification, that might result in financial loss to the Government, it does not encompass those instances of regulatory noncompliance that are irrelevant to the government's disbursement decisions. ${ }^{164}$

161. Brooker, supra note 38 , at 400 .

162. S. REP. NO. 99-345, at 1 (1986), reprinted in 1986 U.S.C.C.A.N. 5266, 5266 (emphasis added).

163. Mikes v. Straus, 274 F.3d 687, 696 (2d Cir. 2001) (citing United States ex rel. Marcus v. Hess, 317 U.S. 537, 549, 551-52 (1943)).

164. Id. at 697 (internal quotations and citations omitted). 
Additionally, Congress described the FCA as a "tool used to recover funds lost to fraud and abuse," 165 and in no way described the Act as punitive. ${ }^{166}$ Because it is clear that the Act's primary purpose is restitutionary, courts should not use it to punish all claimants who inadvertently make false statements that are irrelevant to the decisionmaking entity in its decision-making process.

\section{B. The Natural Tendency and Outcome Determinative Tests Are Flawed and Inappropriately Applied By Some Courts}

While no judicially created test is without its shortcomings, the natural tendency and outcome determinative tests are seriously flawed. Courts are having difficulty applying the tests consistently among FCA violators. The natural tendency test is far too broad, which could cause inconsistent outcomes among claims under the FCA. It also imposes a more punitive aspect on claims under the FCA, despite the clear restitutionary purpose of the statute, by punishing claims that were not meant to be within the purview of the statute. The outcome determinative test is too strict and severely weakens the fraud deterrent effect of the statute and ability of the government to protect its federal relief funds and assistance programs during this current economic crisis. Additionally, some courts professing to apply one test seem to use the requirements of the other.

\section{Natural Tendency Test}

A serious problem with the natural tendency test is that there is no standard by which to measure how influential the false claim or statement must be. Any small error in the claim or in a statement could "potentially" affect the government's decision to pay, but what is unclear is the level of potentiality the statement or claim must have before it is considered material. The courts are silent on this issue, and Congress's general definition of "material" provides no guidance. Allowing such broad discretion could cause severe discrepancies between similar cases in front of different courts. Even if both courts profess to apply the natural tendency test, one court may take the view that the claim did not have enough potential or "natural tendency to influence," while another

\footnotetext{
165. S. REP. No. 111-10, at 10 (2009), reprinted in 2009 U.S.C.C.A.N. 430, 438.

166. Although the Senate Report cites Congress's aims to punish and prevent fraud, these aims are confined to the criminal provisions FERA amends as opposed to the FCA's civil provisions. See id. at $6-15$.
} 
may find the opposite and impose liability under the FCA. The disparate treatment of what constitutes fraud among circuits can lead to overdeterrence of conduct that does not actually violate the FCA, especially in the current climate of hypersensitivity to fraud.

By applying such a broad test for determining materiality, the natural tendency test sweeps in many false statements and claims that were not intended to be within the purview of the statute. By requiring those submitting these claims to pay the $\$ 10,000$-per-false-claim forfeiture, the courts are assigning a punitive aspect to the FCA that was not originally intended by Congress. As articulated in the Sixth Circuit, these courts believe that when Congress increased the fine from $\$ 2000$ to $\$ 10,000$ with the 1986 amendments, it implied that the statute was meant to be more punitive in nature. ${ }^{167}$ This assumption cannot be true. A simple inflation calculation completely contradicts this notion. Two thousand dollars in 1863 is equal to approximately $\$ 17,850$ in $1986 .{ }^{168}$ This calculation actually leads to the conclusion that Congress intended to adjust the penalty for inflation and decrease the punitive effect of the civil penalties. Additionally, in considering the 2009 amendments, Congress had the opportunity to raise the civil penalty but did not and merely provided an inflation adjustment provision. ${ }^{169}$

Additionally, in unique cases under the natural tendency test, a person may be held liable and subject to $\$ 10,000$ in civil penalties when the false claim had the effect of causing the government to underpay the person what he was owed. This situation was discussed in the Fourth Circuit in United States ex rel. Schell v. Battle Creek Health System. ${ }^{170}$ The court analyzed a hospital's cost and billing methods for anesthesia provided to patients. ${ }^{171}$ The hospital received Medicare funds incrementally based upon cost estimates without regard to the billing methods. ${ }^{172}$ While the court found that the hospital's method of billing patients could have constituted fraud on Medicare, ${ }^{173}$ the reports to Medicare only consisted of the cost of the medicine and not what had been billed to the patients. ${ }^{174}$ However, as Judge Cook pointed out in his dissent, "Medicare did not suffer damages_-instead, Medicare underpaid

167. United States ex rel. A+ Homecare, Inc. v. Medshares Mgmt. Group, Inc., 400 F.3d 428, 446 (6th Cir. 2005).

168. See The Inflation Calculator, http://www.westegg.com/inflation/ (last visited Oct. 1, 2009).

169. 31 U.S.C.A. § 3729(a)(1)(G) (West Supp. 2009).

170. 419 F.3d 535, 539 (6th Cir. 2005).

171. Id. at $536-37$.

172. Id. at 537.

173. See id. at 540 .

174. Id. at 538-39. 
in its interim payments to [the hospital] ... such that Medicare owed [the hospital] money 'at the end of the day." "175 In essence, the alleged violation did not harm the government; in fact, the government may have underpaid the Medicare costs of the defendant. ${ }^{176}$

Circuits applying the natural tendency test have been imposing liability under the FCA as if it is a punitive statute. To the contrary, the FCA was intended to be restitutionary, and the additional civil penalty of $\$ 10,000$ was to ensure that the government was entirely reimbursed for its loss. ${ }^{177}$ These discrepancies and inconsistent outcomes regarding fraud under the FCA are undermining the aim of the FCA - to deter fraud against the government. Additionally, these courts are attempting to convert the purpose of the statute from restitutionary to punitive in nature. This strict punitive interpretation is not what the drafters of the FCA intended.

\section{Outcome Determinative Test}

There are also problems with the restrictive outcome determinative test. While the purpose of the FCA is remedial in nature, "there is no language in [§] 3729(a)(1) that mandates actual payment by the government or the need to establish damages." 178 In fact, "[t $t$ he statutory language supports the view that proof of damages is not a prerequisite for suit under the FCA."179 Therefore, the outcome determinative test would not find a person liable who satisfies all the elements of the FCA if the government happened to catch the falsity before it paid the claim. Essentially then, this test puts substantial weight on the government's actions to determine the materiality of the claim and not on the nature of the defendant's statements or claims. This situation also undermines the fraud deterrent aim of the FCA because of the potential inconsistent application of the statute.

The outcome determinative test forces courts to apply the statute narrowly and restrictively, which decreases its deterrent effect and makes protection of government funds from fraud more difficult. Additionally,

\footnotetext{
175. Id. at 543 (Cook, J., dissenting). An expert for Battle Creek concluded that the cost-tocharge ratio by which Medicare was to pay Battle Creek barely changed through the 1990s and may have even caused Medicare to underpay Battle Creek. This expert's testimony was unchallenged by the plaintiff. Id.

176. Id.

177. United States v. Bornstein, 423 U.S. 303, 314 (1976) (quoting United States ex rel. Marcus v. Hess, 317 U.S. 537, 551-52 (1943), superseded by statute, 31 U.S.C. $§ 3730$ (2006)).

178. Brooker, supra note 38 , at 394 (emphasis added).

179. Krause, supra note 149, at 163-64.
} 
there cannot be a deterrent effect if what constitutes fraud is dependent solely on whether the government happens to catch the false claim or statement. The 1986 amendments indicate that while the main purpose of the damages under the statute are remedial in nature, the treble damages impose a slight punitive aspect. Based on the plain text of the statute, Congress meant for persons submitting false claims to be held liable, even if the government happens to catch the false claims before payment has been made. The outcome determinative test is too restrictive to further the fraud deterrent purpose of the statute.

\section{Cross-Application of the Two Tests}

In addition to the fact that the natural tendency and outcome determinative tests are flawed, courts experience great difficulty in applying these tests to materiality under the FCA. The circuits are confused about what the tests require and how to appropriately and consistently apply them. Some courts professing to apply one test have seemingly applied the other.

For example, the Fourth Circuit in applying the natural tendency test disallowed recovery because the false statements in question were not "central" to the funding decision by the governmental entity. ${ }^{180}$ In United States ex rel. Berge v. Board of Trustees of the University of Alabama, the plaintiff alleged that the defendants made false statements to the National Institutes of Health in their annual progress reports for grants. ${ }^{181}$ A government officer indicated that the false statements "were not central to UAB's project and that the progress reported by UAB was satisfactory for a recommendation of continued funding without [the false statements]."182 Therefore, the court held that the false statements were not material. ${ }^{183}$ Because the court looked at whether the statements were "central" to the government's decision to pay the claim and at whether the claim would have been paid without the statements, the court was trying to determine if the false statements would have affected the outcome or the government's decision to pay. If the court were truly applying the natural tendency test, it would be analyzing whether the false statements had the potential to affect the decision of the government, not whether the statements actually affected the outcome. 
The uncertainty of what test courts will apply only exacerbates the problem that the FCA is not consistently applied and further undermines the fraud deterrent purpose of the statute.

While no judicial test is perfect, especially one for a vague and elusive concept like materiality, the natural tendency and outcome determinative tests are failing to further the purpose of the statute. Instead, these tests are actually undermining the statute's aims of protecting government funds from fraud and abuse and deterring fraud. Additionally, in the current economic climate where financial fraud is constantly in the limelight and deterrence is a very important tool, it is critical that courts apply a unified standard. The courts need a test that is consistent with Congressional intent, furthers the purposes of the FCA, and can be more consistently applied in all courts across the country.

\section{The Test for Materiality Under the FCA Should Be the Substantial Weight Test}

Because the natural tendency test is too broad and the outcome determinative test is too restrictive, courts need a test that balances the remedial and punitive aspects of the FCA. The courts should apply a substantial weight test for materiality under the FCA. Because the statute provides for a civil penalty in addition to damages, the government need not actually suffer damages for a defendant to incur liability under the FCA. However, the false claim or statement must be given substantial weight by the governmental decision-making entity-it must be one that the government typically considers when making decisions to pay similar claims. If the false statement or claim is trivial and is not given substantial weight in the decision-making process, it is outside the purview of the statute, and the claimant cannot incur liability under the FCA. The Supreme Court has developed a similar test for materiality under different statutes. Additionally, the text and purpose of the statute supports such a test.

1. The Supreme Court Supports the Substantial Weight Test in Other Legal Contexts

A test similar to the substantial weight test for materiality is used in the context of torts. The Restatement (Second) of Torts provides a general definition of materiality and advises that a matter is material if

(a) a reasonable man would attach importance to its existence or nonexistence in determining his choice of action in the transaction in question; or (b) the maker of the representation knows or has reason to 
know that its recipient regards or is likely to regard the matter as important in determining his choice of action, although a reasonable man would not so regard it. ${ }^{184}$

The Restatement definition, among several other tests, has been applied by the Third Circuit in analyzing whether a statement was material in the context of the FCA. ${ }^{185}$ The circuit cited Neder as authority for using the definition. $^{186}$

The Supreme Court in Kungys v. United States considered a test bearing significant similarities to the proposed substantial weight test under a denaturalization statute. ${ }^{187}$ Four Justices found "Kungys's misstatements of his date and place of birth on his naturalization application not material because those statements were neither relevant to citizenship qualifications nor, if correctly reported, would they have led to other facts relevant to qualifications for citizenship."188 The Court's analysis is similar to the substantial weight test because it considers whether the misstatements would be given any weight by the naturalization board in its decision regarding Kungys's citizenship qualifications.

The Supreme Court's decision in TSC Industries, Inc., v. Northway, Inc. lends even stronger support for the use of the substantial weight test for determining materiality under the FCA. ${ }^{189}$ The Court considered the definition of "material" under the proxy rules under the Securities Exchange Act of 1934. ${ }^{190}$ The proxy rules under this Act bar the use of "proxy statements that are false or misleading with respect to the presentation or omission of material facts." question of materiality is "an objective one, involving the significance of an omitted or misrepresented fact...."192 It also recognized that the rule's "broad remedial purpose" was important in formulating a standard of materiality. ${ }^{193}$ The Court considered a test that was adopted by the

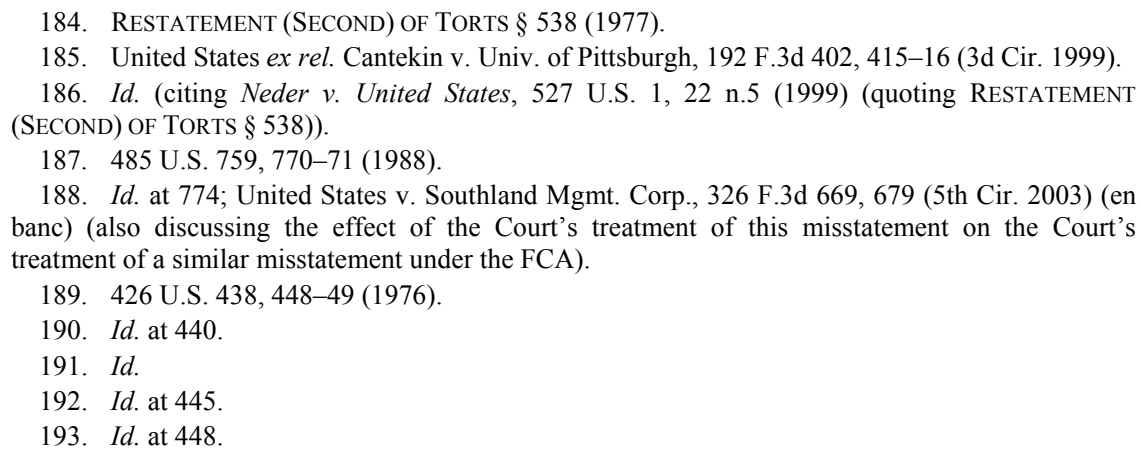


Court of Appeals, which found a statement to be material if a reasonable shareholder might consider it important. ${ }^{194}$ It criticized that "the 'might' formulation is 'too suggestive of mere possibility, however unlikely.", 195 Accordingly, the Court formulated the following test: "An omitted fact is material if there is a substantial likelihood that a reasonable shareholder would consider it important in deciding how to vote."196 The Court further explained that the standard contemplates a showing of

a substantial likelihood that, under all the circumstances, the omitted fact would have assumed actual significance in the deliberations of the reasonable shareholder. Put another way, there must be a substantial likelihood that the disclosure of the omitted fact would have been viewed by the reasonable investor as having significantly altered the "total mix" of information made available.

In formulating this test for materiality, the Court considered the balance between "the need to insure adequate disclosure and the need to avoid the adverse consequences of setting too low a threshold for civil liability."198 In later decisions, the Supreme Court adopted this materiality formulation in numerous other securities contexts. ${ }^{199}$

Because materiality in the context of securities and in the context of the FCA both deal with fraud under a federal statute, the careful consideration by the Supreme Court in TSC Industries of the purpose of the securities statute and the weakness of other tests applies equally to the FCA. Even though the FCA has a broad remedial purpose, the Supreme Court would likely criticize the natural tendency test as "too suggestive of mere possibility" as it did in TSC Industries. Instead, the materiality requirement under the FCA permits courts to carefully balance the need to deter fraud and ensure the claims are truthful and legitimate against the adverse consequences of setting civil liability too low and punishing those defendants whose actions are not within the purview of the statute. Finding liability under the FCA when false statements or claims are given substantial weight in the decision-making process serves to balance these competing interests and further the remedial purpose of the statute.

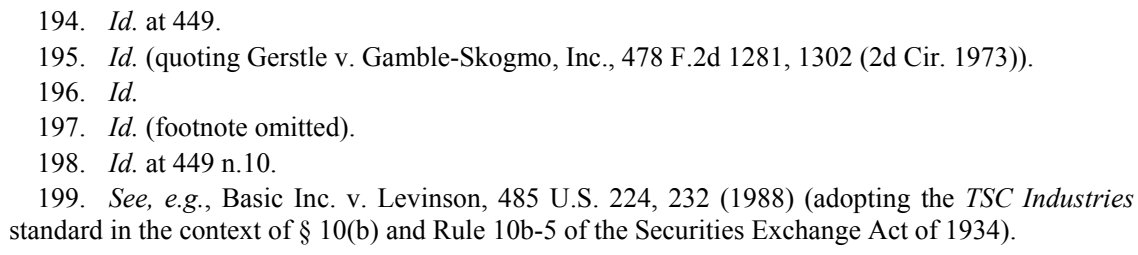


2. A Plain Reading of the Text and the Purpose of the FCA Support the Substantial Weight Test

To tailor the test for materiality to the FCA, it is important to look to the text of the statute. The FCA imposes liability upon a person who "knowingly makes, uses, or causes to be made or used, a false record or statement material to a false or fraudulent claim." ${ }^{200}$ Although the phrase "to get" was written out of the statute with the 2009 amendments, Congress's reasoning for doing so was to ensure that courts would not interpret "to get" as an intent element rather than to help define the test for materiality. ${ }^{201}$ As a result, it is useful to look at the prior phrasing of the Act to ascertain what Congress meant in drafting the statute and to determine the purpose implied in the text.

Prior to the 2009 amendments, one subsection of the FCA imposed liability on anyone who "knowingly makes, uses, or causes to be made or used, a false record or statement to get a false or fraudulent claim paid or approved by the Government." ${ }^{202}$ Completely setting aside the issue of intent, courts used the phrase "to get" to interpret a materiality requirement. ${ }^{203}$ The reasoning was that the use of a false statement could only serve to induce the government to disburse money if it was material to the claim. ${ }^{204}$ Thus, liability under the FCA does not arise only because the claim includes a false statement, but "the claim itself must be false or fraudulent." 205 "A false statement within a claim can only serve to make the entire claim itself fraudulent if that statement is material to the request or demand for money or property." 206 A statement cannot be material to the request or demand for money or property unless it is one that is given significant weight in the decision-making process by the governmental entity or contractor.

200. 31 U.S.C.A. § 3729(a)(1)(B) (West Supp. 2009).

201. S. REP. NO. 111-10, at 13 (2009), reprinted in 2009 U.S.C.C.A.N. 430, 440-41.

202. 31 U.S.C. § 3729(a)(2) (2006), amended by 31 U.S.C.A. § 3279(a)(1)(B) (West Supp. 2009). Congress removed the phrase "paid or approved by the Government" to prevent courts from interpreting the statute to require direct governmental involvement as opposed to indirect use of governmental funds, and not whether the claim must actually be paid to be considered material. S. REP. No. 111-10, at 12 (2009).

203. See supra Part III.A.1.a; see, e.g., United States v. Southland Mgmt. Corp., 326 F.3d 669, 679 (5th Cir. 2003) (en banc).

204. Id.

205. United States ex rel. A+ Homecare, Inc. v. Medshares Mgmt. Group, Inc., 400 F.3d 428, 443 (6th Cir. 2005).

206. Id. (citing United States ex rel. Wilkins v. N. Am. Constr. Corp., 173 F. Supp. 2d 601, 624 (S.D. Tex. 2001)). 
Essentially then, under the FCA, a person cannot submit a record or statement material to a claim unless the statement is clearly one typically considered by the governmental entity in determining which claims to pay. Therefore, to further the broad remedial purpose of the statute and to maintain consistency with how the Supreme Court has interpreted the FCA, the test for materiality should be the substantial weight test.

While the proponents of the outcome determinative test may criticize the substantial weight test as more difficult to apply, the Supreme Court has declared that "ease of application alone is not an excuse for ignoring the purposes of [statutes] and Congress' policy decisions."207 Additionally, because the "determination of materiality is contextspecific and sensitive to what the government accomplishes by means of [enforcing the statute]," 208 the test must provide flexibility to different situations. The substantial weight test provides this flexibility by allowing courts to perform a case-by-case analysis of whether the false claim or statement is one that would typically be given substantial weight in the governmental entity's decision-making process.

\section{CONCLUSION}

The current status of materiality within the context of the FCA could force Congress to once again clarify the purpose and amend the statute. For congressional economy, the courts should apply the substantial weight test. While the government need not actually have paid out on the false claim, the alleged false statement must be the type often considered by the government in the decision-making process, and its effect must be given substantial weight in the government's decision to pay the claim. This test is consistent with the general definition set forth by the Supreme Court in Neder and with the purpose of the FCA as set forth in the legislative history. Courts would be able to apply this test for materiality more uniformly and, thus, the FCA would be interpreted more consistently by different courts, which would increase the fraud deterrent effect of the FCA. The substantial weight test would more effectively further the underlying purposes of the FCA.

207. Basic Inc. v. Levinson, 485 U.S. 224, 236 (1988).

208. United States v. Southland Mgmt. Corp., 326 F.3d 669, 679 (5th Cir. 2003) (en banc) (Jones, J., concurring). 